\title{
ESTABLISHMENT OF SWIMMING POSTURE TEACHING MODEL BASED ON INTEGRATED ALGORITHM
}

\author{
ESTABELECIMENTO DO MODELO DE ENSINO DE POSTURA NA NATAÇÃO BASEADONO \\ ALGORITMO INTEGRADO \\ ESTABLECIMIENTO DE UN MODELO DE ENSEÑANZA DE LA POSTURA DE NATACIÓN BASADO \\ ENALGORITMOS INTEGRADOS
}

\author{
Jingjing Wang' ${ }^{1}$ \\ (Public Health Education) \\ Anping Chen' (D) \\ (Psychology) \\ Shichao $X_{i a}^{2}$ (ID \\ (Mental Health)
}

1. School of Physical Education,

Shanxi University, Taiyuan, Shanxi,

030006, China.

2. Swimming Centre, Taiyuan,

Shanxi, 030021, China.

Correspondence:

Taiyuan, Shanxi, 030006, China. tmzbtt213gx798@126.com

\begin{abstract}
As people's lives become better and better, more and more citizens are no longer satisfied with simple food-and-clothing problems, but gradually move towards the spiritual life they are yearning for. Among this, physical health is also an important part of it. So, at this stage, a lot of people will go swimming to exercise their body and mind. In this paper, the integration algorithm was used, and the self-learning ability of the integration algorithm was used. This algorithm was used to study the swimming posture model. This model can play an important role in the teaching of traditional swimming posture.
\end{abstract}

Keywords: Algorithm; Posture; Swimming.

\section{RESUMO}

Àmedida que a vida das pessoas se torna melhor, cada vez mais cidadãos já não se contentam com problemas simples como comida e vestuário, mas, gradualmente, passam a cuidar da vida espiritual que anseiam. Nesse contexto, a saúde física é também um fator importante. Então, nesse estágio, muita gente passa a fazer natação para exercitar o corpo e a mente. Neste artigo, utilizou-se o algoritmo de integração, além da capacidade de autoaprendizagem do algoritmo. Utilizou-se o algoritmo para estudar o modelo de postura na natação, que pode desempenhar um papel importante no ensino da tradicional postura de natação.

Descritores: Algoritmo; Postura; Natação.

\section{RESUMEN}

A medida que la vida de las personas se vuelve mejor, cada vez más ciudadanos no se contentan con problemas simples como la comida y la vestimenta, sino que gradualmente, empiezan a cuidar la vida espiritual que anhelan. En ese contexto, la salud física es también un fator importante. Entonces, en ese nivel, mucha gente comienza a hacer natación para ejercitar el cuerpo y la mente. En este artículo, se utilizó el algoritmo de integración, además de la capacidad de autoaprendizaje del algoritmo. Se utilizó el algoritmo para estudiar el modelo de postura en la natación, que puede desempeñar un papel importante en la enseñanza de la tradicional postura de natación.

Descriptores: Algoritmo; Postura; Natación.

\section{INTRODUCTION}

Since the implementation of China's reform and opening up in 1987, China's transfer plan economic system is a market economy system with Chinese socialist characteristics. The change of this economic system has become an important reason for China's economic takeoff. After the reform and development of China, the living standard of the people of our country has been greatly improved.' Gals living conditions have done a detailed study of the model. Our needs for life are in the shape of Pyramid. Everyone's spiritual needs are at the top of Pyramid. Our material needs are at the bottom of the gold tower. Health and dietary needs are in the middle of the pyramids. After many investigations, the better the country's living conditions are and their needs will move to the top of Pyramid. At this stage, the people of our country have proved this point very well. ${ }^{2}$ Our country can see this from the change of the living conditions of the people. The living conditions of our national people have changed. Now our nationals need a higher level of demand. So many people go swimming, which is so beneficial to our health. ${ }^{3}$ We can see how hot the sport is from the swimming pool in the street. However, there are many problems in the teaching of swimming at this stage. That's the difference between the coaches' level, some coaches feel more tired and do not teach seriously. ${ }^{4}$

\section{STATE OF THE ART}

The above phenomenon is a very bad behavior for the promotion of swimming at the present stage. So many experts and scholars have conducted a survey of the quality of the coaches mentioned above. The survey showed that most people did not have professional training, and the teaching posture was not correct. ${ }^{5}$ And some swimming institutions are not qualified for teaching. These are the main problems that exist at the present stage of swimming. So can we use some more advanced technology to replace or assist a coach? The answer is yes. A number of scholars have also conducted some related studies. Many scholars have sought a new way to modify and simulate swimming teaching postures. It is necessary to use the swimming posture teaching model. 
A lot of people have tried in this respect, but the effect was not very good. Based on the above problems, we use a swimming posture teaching model based on ensemble learning algorithm to construct our research. The integration algorithm is a learning algorithm. This integration algorithm is often used to improve the precision level of our research objects. In this paper, we use the swimming posture teaching model based on the integrated algorithm. This model can produce image output for the swimming posture. It is also possible for students with incorrect swimming positions to play a role in correcting their swimming posture. To a certain extent, it can be used to replace the work of a swimmer. We set up an integrated algorithm based swimming posture teaching model to help people build the right swimming posture.

\section{METHODOLOGY}

\section{Construction of swimming posture teaching model based on integrated learning algorithm}

Integrated learning algorithm is a kind of learning algorithm. This algorithm has good generalization ability. This ability is reflected in the effective combination of many different fields and different kinds of tasks. This algorithm mainly has the following three functions: one is to improve the accuracy of the prediction. The effective estimation of our test samples has always been the research goal of machine learning. But the single algorithm does not operate above. This is due to the friends of their own defects of the algorithm itself. This inherent defect does not reach such a requirement. So we explore an algorithm that can be integrated and can learn the test data. The integration algorithm is a good solution to this problem. Two is to be able to over fit the elimination. We know that, when our error is eliminated to a certain extent, the algorithm will deviate from the original fitting route. A data source with the best performance is selected at the end of the result. But this data source can have the best comprehensive performance. But the function that we require is not very fit. This problem is a function weight problem. We add weight value analysis to the integrated learning algorithm and solve this problem successfully. The three is to improve the selection of parameters. We know that when we do some other algorithms for model building, we often involve the problem of parameter selection. The problem of this parameter selection cannot be avoided. When we choose the parameters, we often use the experience to select the parameters. But this experience based parameter selection has brought a lot of error. Sometimes this error can't be avoided. We used integrated learning algorithms to build a variety of models for our research. To a great extent, the problem of parameter selection is avoided. The following table is a functional comparison list of integrated learning algorithms and BP neural network algorithms and genetic algorithms. (Table 1)

We can see clearly from the above integrated learning algorithm, the BP neural network algorithm, and the genetic algorithm's functional comparison list. The above three functions of our model need to improve the accuracy of prediction, overfitting elimination and improving

Table 1. A functional comparison list of integrated learning algorithms and BP neural network algorithms and genetic algorithms.

\begin{tabular}{c|c|c|c}
\hline & $\begin{array}{c}\text { The problem of } \\
\text { improving parameter } \\
\text { selection }\end{array}$ & $\begin{array}{c}\text { Improving the } \\
\text { accuracy of } \\
\text { prediction }\end{array}$ & $\begin{array}{c}\text { Overfitting } \\
\text { elimination }\end{array}$ \\
\hline $\begin{array}{c}\text { BP neural network } \\
\text { algorithm }\end{array}$ & Yes & No & No \\
\hline $\begin{array}{c}\text { Integrated learning } \\
\text { algorithm }\end{array}$ & Yes & Yes & Yes \\
\hline genetic algorithm & No & No & Yes \\
\hline
\end{tabular}

parameter selection. The three essential functions of our research are that the ensemble learning algorithm is exactly consistent with the three functional requirements. The BP neural algorithm is mainly used to improve the parameter selection problem. This algorithm is a kind of binary tree algorithm. This algorithm has high generalization ability. It is mainly manifested in its ability to form branches of the tree that we study. These branches can be effectively carried out to get more prediction results. Genetic algorithms are mainly based on the two main shapes of human genetic and gene mutation. The study of these two main shapes makes the algorithm get great progress. This progress mainly eliminates the problem of overfitting. This algorithm gets many prediction results. The results of these predictions bring a certain ability to eliminate the problem of fitting. Based on the characteristics of the three algorithms in the upper table, we have chosen an integrated learning algorithm in this study. But we didn't give up the other algorithms. In this study, we used the BP neural network algorithm and genetic algorithm as the comparison group in the subsequent testing process. (Figure 1)

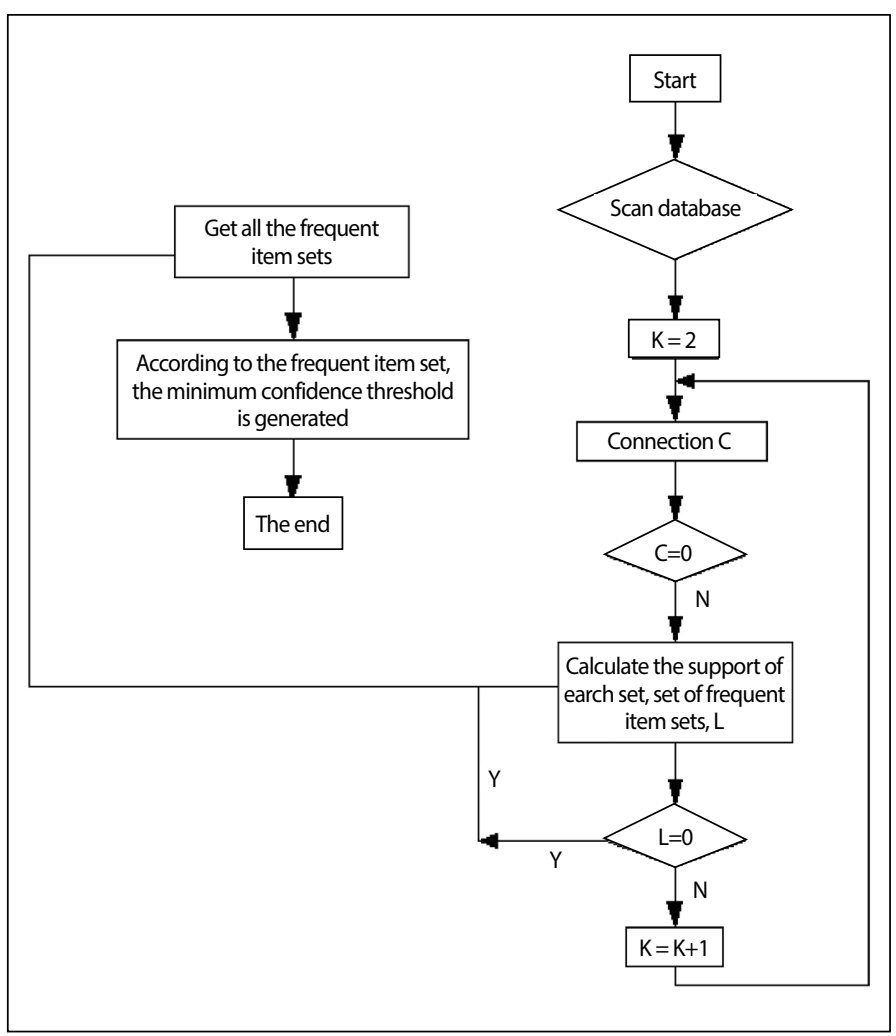

Figure 1. Swimming posture teaching model based on integrated learning algorithm to construct a specific flow chart.

\section{Formula calculation of swimming posture teaching model based on integrated learning algorithm}

The above is the design part of the specific process of the swimming posture teaching model based on the integrated learning algorithm. After the completion of the above part, we have effectively designed the formula calculation part of the swimming posture teaching model based on the integrated learning algorithm. The specific design steps are as follows:

For the regression problem, the output results are synthesized by the weighted average method, and the output of the integrated output is as follows:

$$
F\left(x_{p}\right)=\frac{1}{M} \sum_{i=1}^{M} f_{i}\left(x_{p}\right)
$$


The above $M$ is the output coefficient, and the $F$ is the output of the integrated. The generalization error of each sublearner on the whole data set is as follows:

$$
E_{i}=\sum_{p=1}^{N}\left(y_{p}-f_{i}\left(x_{p}\right)\right)^{2}
$$

The above $\mathrm{E}$ is a generalization error, and $\mathrm{f}$ is a generalization function. The generalization error of the integrated learner output on the whole data set is as follows:

$$
E=\sum_{p=1}^{N}\left(y_{p}-f\left(x_{p}\right)\right)^{2}
$$

The average value of the generalizing error of each sublearner:

$\bar{E}=\frac{1}{M} \sum_{i=1}^{M} E_{i}$

The difference degree of each sublearner is as follows:

$$
A_{i}=\sum_{p=1}^{N}\left(f_{i}\left(x_{p}\right)-F\left(x_{p}\right)\right)^{2}
$$

In the above formula, $A$ is the difference degree of the learner, the $F$ is a differential function, and the $\mathrm{f}$ is a generalization function. The mean value of the different degree of each sublearner is:

$$
\bar{A}=\frac{1}{M} \sum_{i=1}^{M} A_{i}
$$

The following figure is the flow chart of the formula calculation of the swimming posture teaching model based on the integrated learning algorithm. (Figure 2)

From the above calculation formula of swimming posture teaching model based on ensemble learning algorithm, we can see that in order to minimize the generalization error f of the integration, we must weigh the accuracy between sublearner and the difference between sub learning devices. The generalization error cloud of each sublearner is as small as possible. The next table is the generalization performance index of the integrated learning algorithm. (Tabela 2)

\section{RESULT ANALYSIS AND DISCUSSION}

The teaching model of swimming posture has been experimented by scholars very early. This experiment is mainly based on the capture of the actual human body teaching image. Use these captured images to learn swimming students to show them, and to correct their wrong swimming posture. This model can only play an auxiliary role for swimming coaches in the past, and cannot bypass the swimming coaches' personal one to one communication for swimming students. The one to one communication we refer to here is that our model can be caught at any time and in the swimming position of the swimmers. This kind of swimming instrument is a waterproof instrument that can be worn on the wrist during swimming. The price of this instrument is not expensive. After completing the above part of the swimming posture teaching model construction based on ensemble learning algorithm and the completion of the formula calculation part, we tested the process and algorithm in the next part. We first tested this model. We selected three students with incorrect swimming positions for our test. The results of the test are shown in the following Table 3.

The above guidance effectively changed the wrong understanding of swimming posture at the present stage, and changed their swimming habits, and ultimately for their future swimming training. After this test, we asked the coach about the attitude of the model. They believe that although this model fails to detect the physical condition of the above participants, and it cannot track their health in real time to adapt to their training intensity. But the above model can effectively correct their body swimming posture. This is a great assistant to the swimming coaches. The above is the test of the swimming posture teaching model, and then we tested our integrated learning algorithm, as shown in the following Figure 3.

Because our swimming posture test model contains ensemble learning algorithm, and the effect of the model is better. It verifies the effectiveness of our algorithm from the side. In order to visualized the effect of our integrated learning algorithm, we retested the algorithm. The results of the test are shown as shown in the figure above. From the above, we can see clearly that our two algorithms will fluctuate when calculating a lot of data, compared with the BP neural network algorithm. This wave is most intense in the 50 thousand calculation. We modified this shortcoming in the later study.

Table 2. The generalization performance index of integrated learning algorithm.

\begin{tabular}{c|c|c|c}
\hline & generalization performance & Global correct ratio & Correct rate \\
\hline $\mathrm{E}$ & 7.8 & 2.1 & 7.2 \\
\hline $\mathrm{R}$ & 3.2 & 7.2 & 4.8 \\
\hline $\mathrm{T}$ & 7.8 & 7.5 & 8.6 \\
\hline
\end{tabular}

Table 3. A test result table for three inaccurate swimmers.

\begin{tabular}{c|c|c|c}
\hline Action Coding & Pendulum arm posture & Leg posture & Head posture \\
\hline A & 9.7 & 7.6 & 4.6 \\
\hline B & 7.6 & 7.2 & 8.6 \\
\hline C & 8.2 & 7.9 & 5.6 \\
\hline D & 8.4 & 7.0 & 7.2 \\
\hline
\end{tabular}

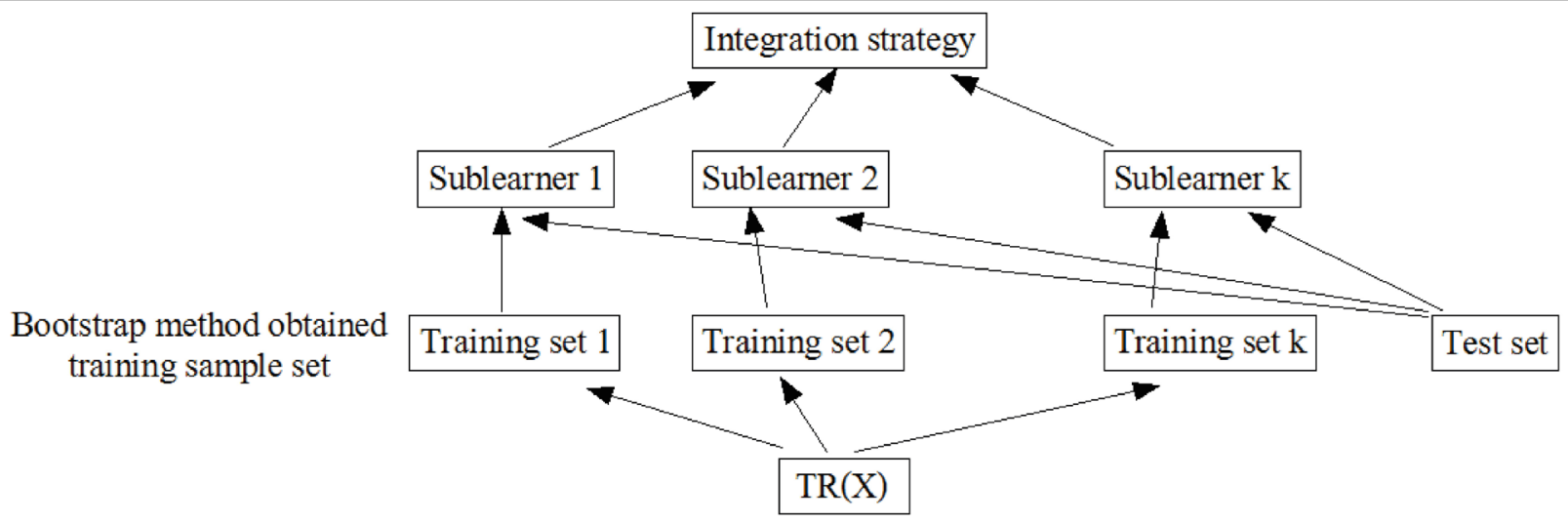

Figure 2. Flow chart of formula calculation for swimming posture teaching model based on integrated learning algorithm. 


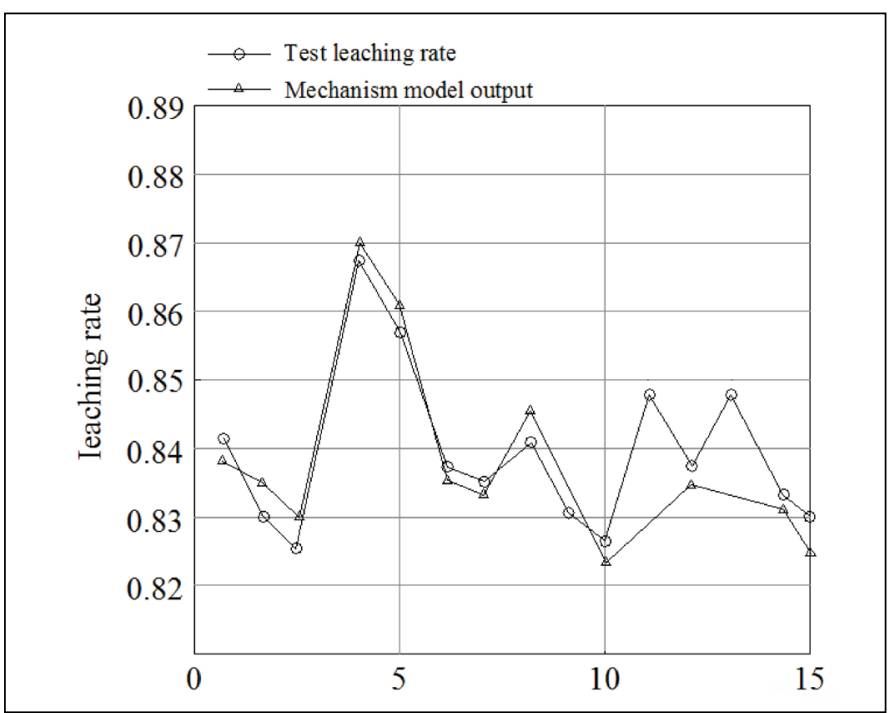

Figure 3. Test result diagram of integrated learning algorithm.

\section{CONCLUSION}

The swimming posture teaching model based on ensemble learning algorithm is mainly composed of camera student swimming posture capture, input training set, algorithm classification training set, training weak learning device, integrated swimming posture correction model, integrated prediction model and so on. Model evaluation is the prerequisite for the validity of the model, and it can also provide guidance for the model updating. In order to improve the generalization ability of the model, an integrated learning algorithm was used in the compensation model. Finally, the prediction results of the compensation model were added to the output of the mechanism model, and the mixture model of the leaching rate was obtained. The simulation of the mixed model shows that the hybrid model has better accuracy than the data model. Therefore, according to the characteristics of the integrated modeling method, the confidence domain of the mixed model is evaluated first. At the same time, in view of the slow time-varying characteristics of the leaching process, the model updating idea based on incremental learning was adopted in this paper when the prediction accuracy of the model cannot reach the requirement. Secondly, the integrated learning algorithm was included in the test model of swimming posture, and the effect of the model is better from the side, and the actual effect of our algorithm was proved. The comprehensive test shows that our research is feasible. However, the suitability of the algorithm is not tested in this study.

All authors declare no potential conflict of interest related to this article

AUTHORS' CONTRIBUTIONS: The author has completed the writing of the article or the critical review of its knowledge content. This paper can be used as the final draft of the manuscript. Every author has made an important contribution to this manuscript. Jingjing Wang; Anping Chen: writing and execution. Shichao Xia: Data analysis.

\section{REFERENCE}

1. Chiba R, Takakusaki K, Ota J, Yozu A, Haga N. Human upright posture control models based on multisensory inputs; in fast and slow dynamics. Neurosci Res. 2016;104:96-104.

2. Lockley T. Promoting international posture through history as content and language integrated learning (CLIL) in the Japanese context. SSLLT. 2015;5(1):87-108.

3. Du M. Establishment of an integrated network platform for English language teaching based on artificial intelligence. Agro Food Industry Hi Tech. 2017;28(1):2165-9.
4. Xing J, Liming XU, Shi L, Gao Z, Yuan Q; College of Engineering,China Agricultural University. Establishment and verification for the simulation model of directional device based on electromagnetic vibration for corn seeds. Journal of China Agricultural University. 2017;5(5).

5. Geng L, Liu P L, Liu K. Optimization of cutter posture based on cutting force prediction for five-axis machining with ball-end cutters. International Journal of Advanced Manufacturing Technology. 2015;78(5-8):1289-303. 